\title{
Comparison of embryological development in the threatened Australian lungfish Neoceratodus forsteri from two sites in a Queensland river system
}

\author{
Anne Kemp* \\ Australian Rivers Institute, Griffith University, 170 Kessels Road, Nathan, Brisbane, Queensland 4111, Australia
}

\begin{abstract}
Lungfish are a relict group of basal fishes, survivors of an extensive fossil fauna that first appeared in the Devonian era. The Australian lungfish Neoceratodus forsteri is the only survivor of this fossil fauna in Australia, and is now confined to only 3 natural environments in southeast Queensland, as well as a few lakes and rivers to which the species has been introduced, all in southeast Queensland. The lungfish is under threat from many aspects of human activity in this highly populated part of the state, notably from conversion of the natural riverine environment into large reservoirs for water conservation where conditions are not ideal for adults or for eggs, embryos and hatchling lungfish. Food in reservoir environments is limited for all stages of the life cycle, and refuges for young fish do not exist because the water level fluctuates, especially in spring when lungfish are spawning. Lack of refuges for small fish has been identified as a possible danger to recruitment of young lungfish to the adult population. Comparison of embryological development between eggs and embryos found in unaltered reaches of the Brisbane River to eggs and embryos from a spawning event in Lake Wivenhoe, where lungfish were trapped when the reservoir was built over the Brisbane River in 1984, suggests that lungfish may face more problems than lack of shelter for the young. None of the material collected from Lake Wivenhoe developed normally, possibly because the level of nutrition for parent fish in this lake was so poor that they were unable to produce viable young.
\end{abstract}

KEY WORDS: Lungfish spawning $\cdot$ Reservoir environment $\cdot$ Nutritional stress $\cdot$ Neoceratodus forsteri $\cdot$ Embryology $\cdot$ Queensland

\section{INTRODUCTION}

Neoceratodus forsteri, the living Australian lungfish, is the sole survivor of an extensive group of related fossil species that once occupied rivers and wetlands in the eastern half of the continent during the mid-Tertiary (Kemp 1997a, 2005). As the continent became more arid and environments changed, many species of lungfish became extinct, leaving 6 in the late Miocene and 3 in the Pleistocene (Kemp 1997a,b). Further changes caused the extinction of 2 of these, and a significant reduction in the environments available for the third, N. forsteri. Natural populations of this fish are now confined to the Brisbane, Mary and Burnett Rivers
(Kemp 1987, 2007, Lissone 2003), and translocated populations occur in the Pine River system, in the Coomera and Albert/Logan Rivers, and possibly in the Condamine River. Another translocated population, in Enoggera Reservoir near Brisbane, where lungfish spawned successfully for many years, has recently become extinct (Brisbane Forest Park rangers, confirmed by Department of Primary Industries Queensland officials, pers. comm.). The remaining populations of lungfish in southeast Queensland are under pressure from human interference with their environment and from natural events such as droughts and periodic flooding of the rivers and lakes in which they live (Bureau of Meteorology Records; www.bom.gov.au/qld/). 
In common with other freshwater fish in altered riverine environments, such as the white sturgeon Acipenser transmontanus of the Columbia River Basin in Canada and the USA (Duke et al. 1999, Bennett et al. 2005), lungfish face problems with the recruitment of juveniles to the adult population. Lungfish are legally protected in Australia by strict federal and Queensland State Government laws, and are listed on CITES level II as 'threatened by trade'. They are not regarded by some government officials as endangered (Queensland Government 2010), at least partly because the species is what might be described as 'locally abundant' in that many adults may be found in a specific locality, such as in the spillway pools below a dam after a flood. However, it is likely that many of these adult lungfish are of considerable age, and few juveniles are ever found in a natural environment (Semon 1893a, Bancroft 1912, 1913, 1918, Kemp 1987, 2007, Kind 2011). Ministers in the Queensland Government nonetheless claim that populations of the Australian lungfish are thriving in dams and reservoirs that are well managed by water authorities (Queensland Government 2010). They do not, at least in public, admit that there could be anything wrong with the lungfish environment or with recruitment of young to the adult population, despite the loss of the entire population of lungfish from Enoggera Reservoir after the water hyacinth Eichornia crassipes was removed in 1974 (Kemp 1987, 2007). The lungfish laid their eggs on this introduced water plant, and its removal destroyed refuges for young lungfish. The population was not renewed, and it eventually became extinct. Government officials insist that the spawning of lungfish in Lake Wivenhoe is a 'good news story' and means that lungfish are flourishing in reservoirs that are managed well by government authorities (Queensland Government 2010).

Creation of water impoundments and reservoirs in the rivers where lungfish normally live has caused the loss of protected habitats for young juveniles (Kemp 1995, 2007), and has reduced the amount of suitable food available for adult lungfish. Often described as omnivorous, the diet chosen by adult lungfish in the wild is actually rather restricted, and consists mainly of small water snails and clams. In addition, adult lungfish are unable to move freely in the river system. These fish grow older and older, and, if recruitment is limited by loss of juvenile habitat and other factors, the population may not be renewed. A further problem occurs during floods, when water is released from the reservoir, and many lungfish are washed over the spillway of the reservoir (Kemp 2007). Large numbers of these fish are injured or killed. Consequences of these changes are potentially devastating for lungfish populations.

Under normal conditions, lungfish return year after year to the same places to lay their eggs (Kemp 1987. 2007). Spawning is triggered by photoperiod, and usually lasts for several months (Kemp 1984). Although there is no parental care, a normal spawning event follows complex courtship rituals involving swimming rapidly together at the surface of the water (Kemp 1984), or chasing each other through banks of water plants such as Hydrilla verticillata (Grigg 1965). When the fish spawn under normal circumstances, they are twined around each other with their vents in apposition, close to water plants such as $H$. verticillata or Vallisneria spiralis, or to the submerged roots of trees such as Callistemon viminalis growing on the river bank, or Eichornia crassipes, with its root masses suspended in the water (Kemp 1984). The latter plant was the preferred species in Enoggera Reservoir, and was often used in the Brisbane River. As each egg is laid, the male sprays milt over the egg and fertilises it. Eggs are large, about $3 \mathrm{~mm}$ in diameter, and covered in several egg membranes with a total diameter of around $1 \mathrm{~cm}$. Because the outer layer of the egg case is sticky for a short time, the egg is usually attached to the mass of roots or plant leaves.

Rainfall, temperature and the lunar cycle have no effect on the spawning of the Australian lungfish, nor is oviposition induced by flooding (Kemp 1984). Availability of water plants does not influence an actual spawning event, although water plants do increase the chances that eggs will be laid in a suitable environment if they are present. Winter floods may wash away the plants that are normally used by lungfish, such as extensive beds of Vallisneria spiralis growing in the shallows, or damage the submerged roots of Callistemon trees on the bank. If plants are missing for any reason, lungfish will shed the eggs into the water column, and many will be carried into deep water and lost (Kemp 2007).

It follows that lungfish will spawn in a reservoir, even if conditions are not entirely suitable for eggs and young. They continued to spawn in Enoggera Reservoir after the water hyacinth was cleared, but in the absence of suitable submerged water plants for the eggs, nothing survived (Kemp 2005, 2007). The issue is not whether the fish will spawn in a water impoundment or reservoir, but whether successful recruitment of juveniles to the adult population is possible under such circumstances. It is not known with any certainty whether recruitment can follow a spawning event in a reservoir with fluctuating water levels that do not allow submerged water plants, such as Vallisneria or 
Hydrilla, to become established in the shallows. Available evidence from Enoggera Reservoir suggests that recruitment is not likely in the absence of suitable refuges for young fish (Kemp 1987, 2007).

Lake Wivenhoe was created from a part of the Brisbane River in 1984, trapping a large number of lungfish behind the wall of the reservoir. Prior to this time, lungfish had spawned regularly in the river and appropriate numbers of juveniles were recruited to the adult population (Kemp 1987). Lungfish may have continued to spawn in the reservoir, as they did downstream of the dam wall. However, if they did, few eggs would have been able to survive in the reservoir because there were no water plants in the shallows to shelter the young fish, and water levels fluctuated wildly in response to the demands made on stored water for farming and for cities downstream of the reservoir.

Heavy rain in the winter of 2009 raised water levels in Lake Wivenhoe and submerged parts of the bank that had been exposed for many years covering areas that had been used for rearing beef cattle (SEQ water records). For several months, the marginal areas of the lake consisted of shallow water, rotting paddock grass and cattle faeces. Filamentous algae filled much of the water to a depth of about $80 \mathrm{~cm}$. In the spring of 2009, at Logan's Inlet in Lake Wivenhoe, numerous lungfish eggs were laid into this environment, scattered among the only available materials in the reservoir, consisting of filamentous algae and the detritus on the substrate.

Lungfish development has been followed in material from a range of river and lake environments (Bancroft 1918, Kemp 1982, 1999, Semon 1893a), and external characteristics of normal development are understood better in this species than in other fish from similar environments. Consequently, analysis of lungfish development is of value as an indicator of good or poor environments, in conjunction with other techniques of conservation physiology, to identify mechanisms associated with the decline of endangered wild populations (Wikelski \& Cooke 2006).

The present study describes preliminary results of a morphological study of eggs and hatchlings from this unusual and aberrant spawning event and compares the material collected in Lake Wivenhoe to specimens collected previously in a site below the wall of the reservoir.

\section{MATERIALS AND METHODS}

Material from an unaltered site in the Brisbane River, at Lowood below Lake Wivenhoe, collected between the years 1990 and 2000, was used for comparison with the eggs from Logan's Inlet in Lake Wivenhoe (Fig. 1), collected during the spawning season of 2009 between mid-August and early October. The Logan's Inlet locality was also searched on several occasions between August and October 2010, but only 4 eggs were found. Stages of development and condition of the eggs were assessed on collection and on arrival in the laboratory. The latter assessment was more detailed because the eggs could be examined under a microscope. Living eggs are olive green or brown and enclosed in jelly membranes that may collect some debris. Eggs that were not fertilised, or have died, vary in colour from bright green to orange. On arrival in the laboratory, eggs were transferred to clean culture medium. Numbers of dead and inviable eggs were also recorded on arrival and on the day following collection, respectively.

Collection methods were different for the 2 localities, because of dissimilarities in the environments where eggs were found. In the river locality, submerged roots were searched by hand, and the same areas were examined twice to ensure that no eggs were missed. This method minimised damage to the weed bank, and was possible because of the large size of the eggs, with a jelly coat $1 \mathrm{~cm}$ in diameter. Eggs that had died and eggs that had been eaten by predators, leaving an empty jelly coat (Kemp 1994), were collected along with living eggs. In Lake Wivenhoe, the eggs were shed into open, shallow water, and were collected by dragging nets over the substrate and searching the collected material for eggs.

All eggs and embryos were reared in captivity by standard methods (Kemp 1981, 1999). The culture

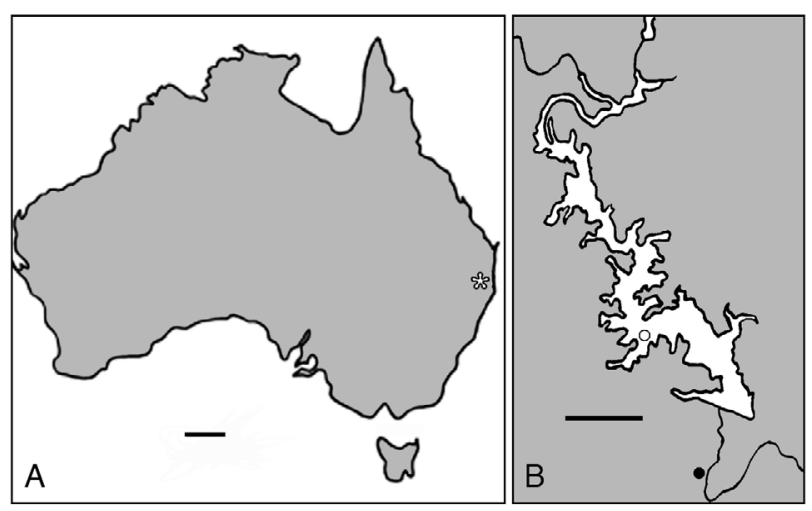

Fig. 1. Two areas where lungfish Neoceratodus forsteri eggs were collected. (A) Australia, with star marking the position of Lake Wivenhoe in the Brisbane River system in south-east Queensland. Scale bar $=300 \mathrm{~km}$. (B) Outline of Lake Wivenhoe and part of the Brisbane River. O: Logan's Inlet within Lake Wivenhoe. - Lowood in the Brisbane River below the wall of Lake Wivenhoe. Scale bar $=10 \mathrm{~km}$ 
medium $(0.75 \%$ sodium chloride) was prepared with rain water, dishes were covered to prevent evaporation, there were weekly changes of one-third of the medium in each dish, and the eggs were not exposed to direct light. The medium was $2 \mathrm{~cm}$ deep in the dishes for young eggs, and $3 \mathrm{~cm}$ deep in small tanks for hatchlings, so oxygen levels should have been adequate for the specimens. Eggs, embryos and young fish were kept under cool ambient conditions. Temperatures under which the eggs were raised ranged from 15 to $20^{\circ} \mathrm{C}$ in August, 16 to $24^{\circ} \mathrm{C}$ in September, 18 to $27^{\circ} \mathrm{C}$ in October and 20 to $28^{\circ} \mathrm{C}$ in early November. These temperatures are within the range for temperatures in the Brisbane River at similar times of the year (Kemp 1984).

Specimens were assessed daily for developmental progress, and samples were taken as required. When the hatchlings reached stages where they were expected to feed, they were transferred to tanks provided with a clump of filamentous algae for a refuge, and offered small crustaceans or black worms as food. Work on Logan's Inlet fish lasted for $10 \mathrm{wk}$ before the last of the hatchlings died.

Specimens from each locality were anaesthetised with an overdose of benzocaine, fixed in $10 \%$ neutral buffered formalin and kept in formalin under refrigeration until they were required for analysis. Fixed material was divided into 2 groups. A series of 50 eggs, embryos and hatchlings from stages 25 to 49 (see Kemp 1982) was set aside to serve as a reference collection. A second series of 50 specimens from stages 25 to 47 was prepared for ultrastructural analysis.

For scanning electron microscopy (SEM), specimens were removed from the egg membranes when necessary, rinsed in several changes of water, dehydrated in a graded series of alcohols, dried in a critical point dryer and mounted on aluminium stubs. They were coated with platinum and viewed in an LV 6460 scanning electron microscope to assess normal structures and anomalies on whole specimens. A representative series of egg membranes was similarly treated to assess the structure and potential anomalies in the membranes.

\section{RESULTS}

\section{Conditions under which eggs were collected}

At Lowood on the Brisbane River below Lake Wivenhoe, eggs were laid on the submerged rootlets of trees (Callistemon viminalis) growing on the bank of the river in full shade. Water depths varied from 5 to $40 \mathrm{~cm}$ where the eggs were found. Eggs were attached individually to the rootlets and were often buried within the root mass. The submerged roots in this locality were in flowing water, and temperatures varied from 18 to $24^{\circ} \mathrm{C}$. Some eggs were shed into the water column, especially in years when spawning was prolific, and many of these were washed into the root masses soon after spawning. Eggs were collected weekly while the spawning season lasted, from August to December in most seasons. Some seasons were shorter, and eggs were found only during September and October.

In Lake Wivenhoe at Logan's Inlet, eggs were laid in still water of 30 to $50 \mathrm{~cm}$ depth, and temperatures at these depths were moderate, no higher than $22^{\circ} \mathrm{C}$ at the time of collection. There was no shade in this locality. Eggs were caught in strands of filamentous algae, or fell into rotting grass lying on the substrate. Temperatures of water in the shallows, around $5 \mathrm{~cm}$ deep, at the edge of the reservoir where no eggs were found, were higher, up to $30^{\circ} \mathrm{C}$. Eggs were collected at weekly intervals from late August to early October.

\section{Viability and stages at collection}

\section{Lowood material}

The percentage of eggs from Lowood collected from 1990 to 2000 that were dead on collection or dying within $1 \mathrm{~d}$ of collection varied from 7 to $35 \%$ (Table 1 ).

Table 1. Neoceratodus forsteri. Percentages of Australian lungfish eggs in different developmental categories (1 to 6) collected in the Brisbane River system, Queensland. Categories are as follows: 1 , Cleavage $2 \mathrm{~d}_{i} 2$, Blastulae $+3-4 \mathrm{~d}_{i} 3$, Neurulae $+2-3 d_{i} 4$, Older neurulae $+4-6 d_{i}, 5$, Prehatch +7 $\mathrm{d}_{\text {; }} 6$, Perihatch $+10 \mathrm{~d}$. DIF: dead in field; Inviable: dead on the day following collection. Note that in 1999 and 1996, eggs were not found in Callistemon rootlets at Lowood, and in 2010 at Logan's Inlet, numbers of eggs were too low to be considered (3 dead, 1 inviable)

\begin{tabular}{|c|c|c|c|c|c|c|c|c|c|}
\hline Date & Total & DIF & Inviable & 1 & 2 & 3 & 4 & 5 & 6 \\
\hline \multicolumn{10}{|c|}{ Lowood } \\
\hline 2000 & 100 & 10 & 15 & 21 & 35 & 4 & 7 & 7 & 1 \\
\hline 1998 & 100 & 15 & 13 & 32 & 24 & 12 & 4 & 0 & 0 \\
\hline 1997 & 100 & 13 & 9 & 39 & 15 & 13 & 10 & 1 & 0 \\
\hline 1995 & 100 & 11 & 9 & 21 & 46 & 7 & 4 & 1 & 1 \\
\hline 1994 & 100 & 8 & 11 & 60 & 4 & 6 & 9 & 1 & 1 \\
\hline 1993 & 100 & 2 & 5 & 44 & 28 & 19 & 1 & 1 & 0 \\
\hline 1992 & 100 & 4 & 11 & 45 & 24 & 13 & 2 & 0 & 1 \\
\hline 1991 & 100 & 19 & 12 & 17 & 46 & 5 & 1 & 0 & 1 \\
\hline 1990 & 100 & 19 & 5 & 42 & 22 & 2 & 7 & 3 & 0 \\
\hline \multicolumn{10}{|c|}{ Logan's Inlet } \\
\hline 2009 & 100 & 35 & 15 & 33 & 1 & 1 & 10 & 4 & 1 \\
\hline
\end{tabular}


If the season lasted for $4 \mathrm{mo}$, from mid-August to midDecember, several sets of parents would have laid eggs. In a short season, of 1 or 2 mo, only 1 or 2 pairs of fish laid eggs. Under good environmental conditions, with moderate temperatures $\left(16\right.$ to $\left.23^{\circ} \mathrm{C}\right)$ and clear water, few eggs died at the time of collection or soon afterwards, with $2 \%$ dead in the field (DIF) and $5 \%$ dying the day after collection, as in 1993 (Table 1). In years when the water was turbid, or cyanobacteria were present in large numbers, many more eggs died, as in 2000 , when $10 \%$ of the eggs collected were DIF and $15 \%$ died on the following day (Table 1). Spawning ceased in this locality in 2002.

Eggs collected in any one week during the spawning season were usually only a few days old (Table 1), either cleavage stages 1 to 10 (up to $3 \mathrm{~d}$ old) or blastulae (up to $5 \mathrm{~d}$ old). There were a few neurulae (up to 8 d old) (Kemp 1981, 1982, 1994) and a small proportion of eggs that had reached stages of head development (up to $14 \mathrm{~d}$ old), or were preparing for hatching (up to $21 \mathrm{~d}$ old). A few eggs were close to hatching, which occurs in Brisbane River material at 24 to $30 \mathrm{~d}$ after oviposition (Kemp 1981, 1982, 1994). Very few empty egg cases were found in riverine environments, and no newly hatched fish. Both of these can be found among the water plants if they are present (Semon 1893a, Kemp 1987). However, figures for older eggs were not a valid estimate of the number of eggs that approached hatching in the natural environment because collections of eggs were made every week in the same areas during the spawning season.

\section{Logan's Inlet material}

Half the eggs from Logan's Inlet in Lake Wivenhoe collected in 2009 were dead on collection $(35 \%)$ or died within $1 \mathrm{~d}$ of collection (15\%) (Table 1). Eggs collected from this locality showed a similar range of stages from newly laid to late-stage neurulae (Table 1), as did the material from Lowood. Most of the eggs collected from Logan's Inlet were young and had been laid less than $24 \mathrm{~h}$ prior to collection. There were also a number of neurulae, between stages 25 and 34, and a few eggs of earlier or later stages. Very few were preparing for hatching, and none were at a stage when hatching usually occurs. Large numbers of empty egg cases were found, and no newly hatched fish. The egg cases, which can persist in a still environment for many weeks, were thin and fragile, and all had several large holes. One hatchling, about stage 47, was discovered among the muck and detritus on the substrate.
The prolific spawning of 2009 at Logan's Inlet was not repeated during 2010, although water levels remained high and conditions were similar. Despite searching the inshore environment on 5 occasions in the spawning season, only 4 eggs were found. Three were dead on collection and the fourth died after a few days in culture, without showing any signs of developmental changes.

\section{Lowood specimens}

Progress of development

Eggs from Lowood reared in the laboratory reached hatching at stages 43 to 45 between 24 and $30 \mathrm{~d}$ of age. Losses of eggs and embryos in the laboratory were few. After hatching, they passed through the normal early stage of inactivity, lying on their sides. As they grew, they became more active, took on an upright posture, and began to feed on black worms or small crustaceans, between stages 46 and 48 , over a period of about $6 \mathrm{wk}$. The range of sense organs in the skin increased from a few electroreceptors and mechanoreceptors on the snout, working in conjunction with the eyes, to a complete sensory line system with many mechanoreceptors on the head and along the trunk. Many single electroreceptors were scattered over the head or arranged in pit lines, and others were found on the paired fins. Above and below the lateral line of the trunk were regular lines of electroreceptors. Eyes became less important as the young fish grew larger, and the olfactory organs and gustatory cells in the oral cavity became more significant. Cilia in the outer epidermis declined in numbers and activity as the fish developed.

\section{Analysis}

At oviposition, the egg case is lined by a smooth double membrane with several deep folds but no holes or cracks (Fig. 2). A thick layer of albumen, also double, surrounds the inner membranes. The outer layer of albumen, about $1 \mathrm{~mm}$ thick, is sticky when the egg is first laid, allowing the egg to be attached to nearby water plants or rootlets. This collects dirt and debris rapidly and is soon no longer adhesive. The inner layer of albumen is $2 \mathrm{~mm}$ thick and allows penetration by certain elements, such as filamentous algae. The inner membranes are thin, but impermeable to algae or fungal hyphae. The egg is able to rotate within the egg case, at least until the segmen- 


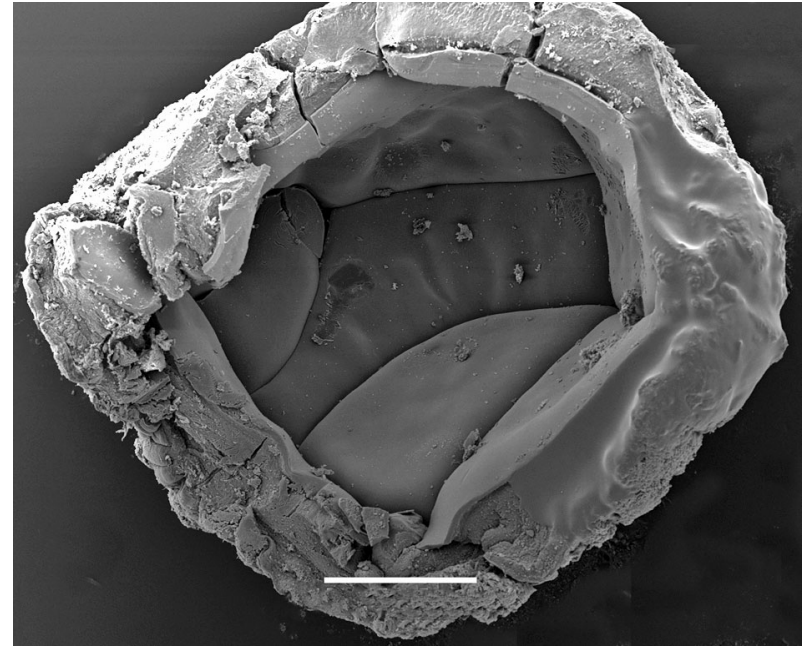

Fig. 2. Neoceratodus forsteri. Membranes of a lungfish egg from Lowood. The membranes were cut in half to show the lining of the egg case where the embryo rests. The inner membranes are complete, and there are deep folds in the lining. Scale bar $=500 \mu \mathrm{m}$

tation cavity of the egg enlarges prior to the onset of gastrulation and the egg fills all the available space (Kemp 1994).

As the embryo grows, develops and begins to move independently within the egg capsule, the inner cavity expands (Kemp 1994). Cracks appear in the inner membranes, and these eventually break and fall to the bottom of the egg case. At the same time, the albumen membranes are digested from within by proteases secreted by the embryo, as in teleost eggs (Hagenmaier 1973, 1974, Iuchi \& Yamagami 1976), and vigorous movements of the young fish enlarge the cavity further. Eventually holes appear in the albumen membranes and the hatchling is able to escape. It uses the egg case as a shelter or a refuge for some time after hatching. At this time, the hatchling has pigmented eyes and a rudimentary set of mechanoreceptors in the lateral line system of the head and trunk, and some electroreceptors on the snout. Under normal circumstances, it avoids light.

Development in embryos and hatchlings from Lowood followed a regular course with little variation (see Figs. 3 \& 4). A normal embryo of stage 31 from this locality consists of a rounded mass of endodermal cells, destined to form the intestine, with myotomes, undifferentiated mesoderm and the developing head and tail curved around the endoderm (Fig. 3A). The brain with traces of the eyes is present below the skin, and a small rounded tail bud lies just behind the developing anus (Fig. 3A). The head with associated structures such as the eyes, gills, oral cavity and olfactory organ develops in advance of the tail, which remains small and rounded (Fig. 3B). Even at this early stage, before the egg membranes have started to expand or to break down, ciliated cells are present in the skin, especially along the groove between the endodermal mass and the trunk musculature. The pronephros lies below the skin as a small round mass behind the developing gills (Fig. 3B).

By stage 36, endoderm has extended away from the head as myotomes form in the mesoderm, and has formed an elongated mass below the trunk musculature. The number of ciliated cells in the epithelium has increased rapidly, except on the belly (Fig. 3C). The pronephros is still visible below the skin and the outlines of the myotomes are visible but not distinct (Fig. 3C). Eyes are present, as are the olfactory organs in the region of the developing mouth, and there are masses below the skin where gills, heart and anterior intestinal structures will develop. The tail bud is a small rounded mass, and there are no skin sense organs. This is the stage where intrinsic muscular activity starts in the embryo, allowing it to flick the head from side to side (Whiting et al. 1992) and incidentally starting the process of expanding the egg case.

By stage 39, the embryo has many cells with cilia in the skin (Fig. 3D). Myotomes are not easy to see below the thick skin, although the outlines of the gill region and the pronephros are still visible. The preanal ventral fin has begun to develop, and the rectum has formed at right angles to the endodermal mass. The pointed diphycercal tail so characteristic of lungfish has appeared (Fig. 3D). In embryos that are approaching hatching (Fig. 3E), the lateral line on the trunk has almost reached the tail, and the operculum is growing over the skin where the gills will open. The primordium of the pectoral fin is present behind the operculum. The lower lip has appeared and is growing forward to meet the upper lip (Fig. 3E). Cilia cover the whole body, and are aligned obliquely above and below the endodermal mass so that their action will sweep particles of matter and settling organisms from the surface. The pre-anal ventral fin is larger and the tail more defined. In the head, eyes are still visible below the skin, and the olfactory opening is present on either side of the developing upper lip (Fig. 3E).

Changes in the head region of embryos and hatchlings are mostly concerned with development of the mouth and sense organs (Fig. 4). By stage 37, the oral cavity has grown deeper, and the developing olfactory organs have appeared at the lateral margin of 

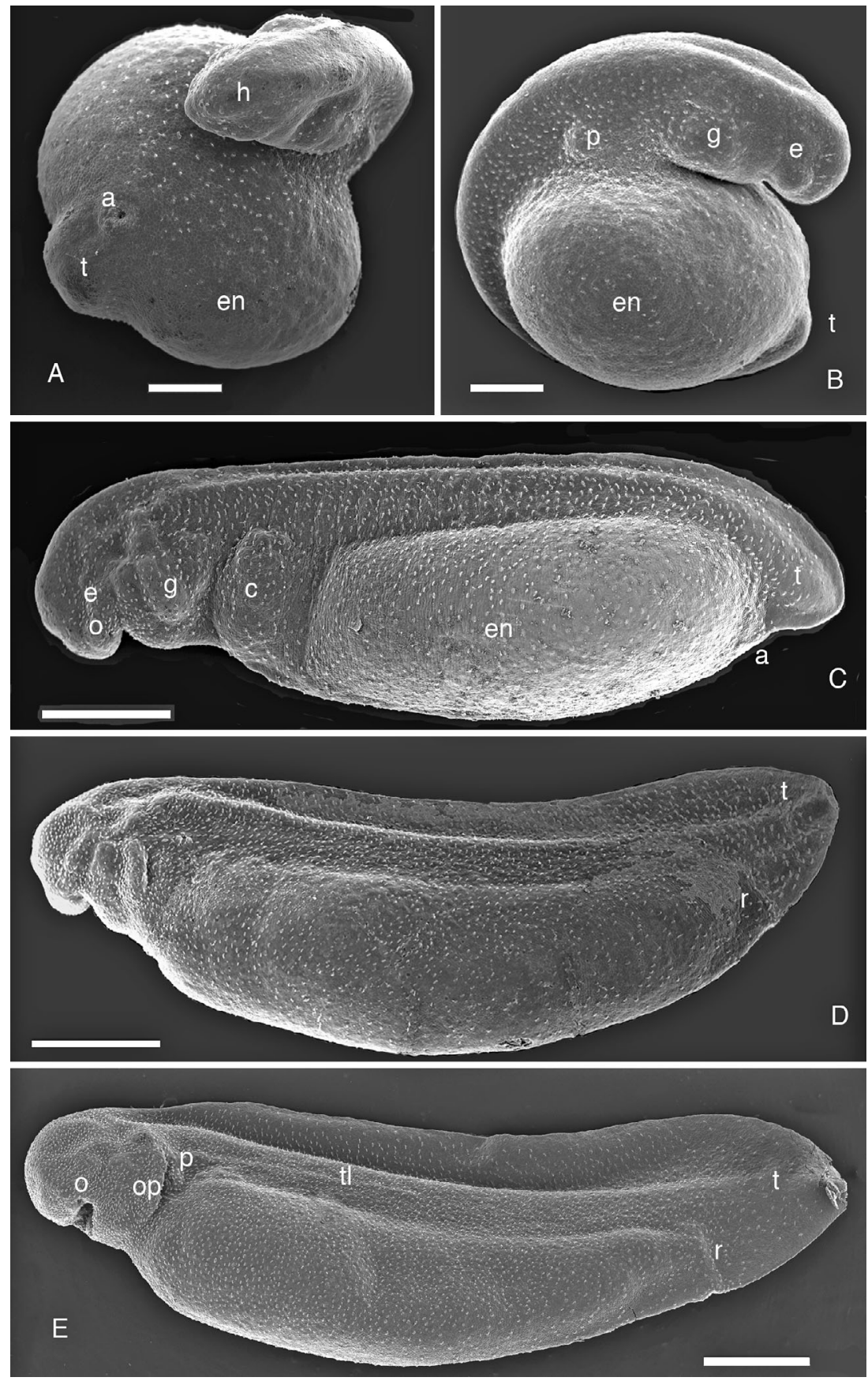

the upper lips (Fig. 4A). At this stage, the operculum begins to grow in the skin covering the gill area, although the gills have not, and do not, open to the exterior. It is still possible to discern the pronephros, now with 3 tubules, below the skin (Fig. 4A). As hatching approaches, the dorsal fin grows as far forwards as the back of the head, and the operculum almost covers the gill area. The lower lip has begun to form, and the mouth still lies on the ventral surface of the head (Fig. 4B). The sensory line of the trunk is visible as a swollen line above the endoderm, and the primordium of the pectoral fin lies behind the operculum.

Changes after hatching are dramatic. The operculum extends to cover the anterior half of the pectoral fin, and is a large bell shaped structure. The olfactory organ has disappeared within the oral cavity, and traces of the sensory line system of the head are present around the eyes and over the snout. The dorsal fin is a wide structure reaching forwards to the head, and gular pits have developed in the lower lip. The mouth is almost but not quite terminal (Fig. 4C).

Differentiation of skin cells begins in embryos before hatching, with a thick plasmalemma on the external surface of all of the cells (Fig. 5). Ciliated cells in the epithelium are the most obvious character of the skin in material from Lowood. Cilia appear in late neu-

Fig. 3. Neoceratodus forsteri. Lungfish embryos from Lowood. (A) Ventral view of a stage 31 embryo showing the developing head, cilia, showing as white marks on the skin, endodermal mass, tail bud and anus. Scale bar $=500 \mu \mathrm{m}$. (B) Lateral view of a stage 32 embryo, with cilia showing as white marks on the skin, developing eye, gill field and pronephros, rounded endoderm and tail bud. Scale bar $=500 \mu \mathrm{m}$. (C) Lateral view of a stage 36 embryo, with endoderm extending, eyes and olfactory organ in the oral region, and masses below the skin where gills, heart and anterior intestinal structures will develop. Myotomes are present but barely visible below the skin, and the pronephros is indistinct. The dorsal and lateral skin is ciliated. Scale bar $=1 \mathrm{~mm}$. (D) Lateral view of a stage 39 embryo, with developing tail fin, and large numbers of ciliated cells in the skin. The rectum is present behind the pre-anal ventral fin, and the myotomes are not visible. Scale bar $=1 \mathrm{~mm}$. (E) Lateral view of a stage 42 embryo, approaching hatching, with well developed lateral line on the trunk. The operculum is growing over the skin where the gills will open, and the primordium of the pectoral fin is present behind the operculum. The lower lip is growing forward to meet the upper lip, and cilia cover the whole body Scale bar = $1 \mathrm{~mm}$. a: anus; c: cardiac region; e: eye; en: endodermal mass; $\mathrm{h}$ : head; g: gill field; o: olfactory organ; op: operculum; p: pectoral fin; pn: pronephros; r: rectum; t: tail; tl: trunk lateral line 

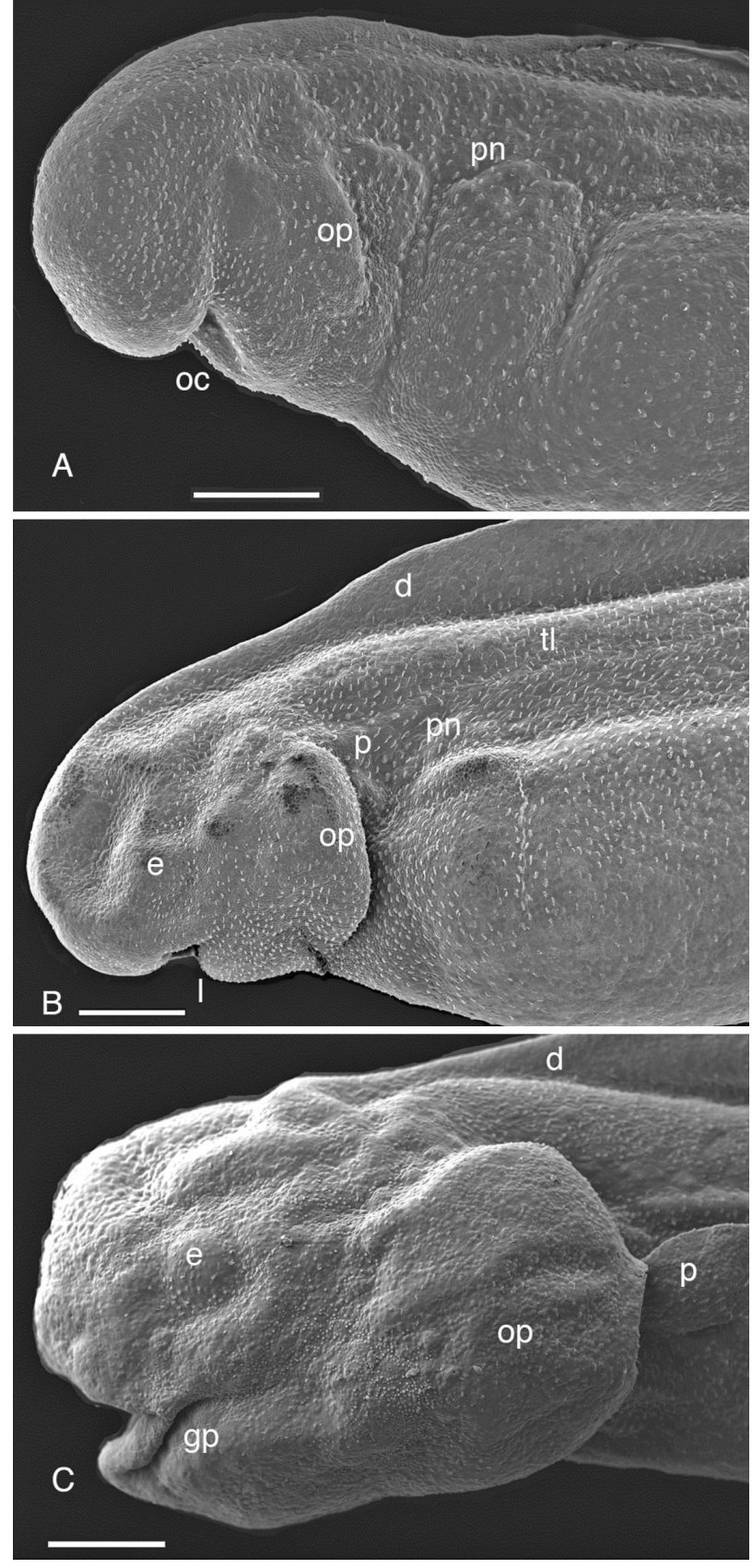

rulae, while yolk globules are still present within the cells. They develop initially on the dorsal surface, and are short and sparse (Fig. 5A). They increase in number and cover the whole embryo before it is ready to leave the egg case. They are found within the developing mouth as well as on the outer epithelium (Fig. 5B). Cells of the external epithelium do not show yolk globules below the cell membrane at this stage (Fig. 5C), but these are still visible in the more heavily yolked endodermal cells of the oral cavity (Fig. 5B). Cilia are active before the embryo leaves
Fig. 4. Neoceratodus forsteri. Details of the heads of lungfish embryos and hatchlings from Lowood, all in lateral view. (A) Head of a stage 37 embryo, showing development of the oral cavity, with the operculum beginning to grow over the gill area, and the pronephros showing above the developing anterior intestine. Scale bar $=500 \mu \mathrm{m}$. (B) Head of a stage 43 embryo, close to hatching, showing the dorsal fin reaching to the back of the head, and the operculum developing to cover the gill slits. The lower lip is forming to cover the oral cavity, and the eye and pronephros are present. The sensory line of the trunk has appeared above the endoderm, and the primordium of the pectoral fin lies behind the operculum. Scale bar $=500 \mu \mathrm{m}$. (C) Head of a hatchling at stage 48 . Openings of the mechanoreceptors of the sensory lines of the head surround the eye, and the dorsal fin reaches to the back of the head. The bell-shaped operculum covers the anterior surface of the pectoral fin. The lower lip has gular pit, and closes the subterminal mouth. Scale bar $=500 \mu \mathrm{m}$. e: eye; d: dorsal fin; gp: gular pits; l: lower lip; oc: oral cavity; op: operculum; p: pectoral fin; pn: pronephros; tl: trunk lateral line

the egg membranes, possibly to prevent dirt and harmful organisms from settling on the skin prior to hatching. Cells that have no cilia have begun to show surface differentiation by stage 40 (Fig. 5C).

Cilia reach full size and activity at stage 44 (Fig. 5D), at about the time of hatching. At this time, many types of skin cells are present on the external epithelium. These are all polygonal, and similar in size, around 20 to $25 \mu \mathrm{m}$. Some have a rough raised surface and some are smooth. Ciliated cells are elongated, with cilia over the full length of the cells (Fig. 5D). They are oriented oblique to the long axis of the hatchling so that the ciliary beat removes particles of dirt from the upper and lower surfaces of the small fish.

For several weeks after leaving the egg case, the hatchling is completely inactive and lies among water plants or rootlets, which are not particularly clean. Presumably the cilia function to remove dirt and settling organisms from the skin surface (Kemp 1996). Young hatchlings lying in a culture dish in the laboratory clear an area around themselves and lie in a little circle of clean water. Ciliated cells decline in numbers and activity after stage 48 , when the hatchling starts to move around.

The developing hatchling has a number of small sense organs in the skin, and these are particularly numerous in the head region (Fig. 5E,F). Electroreceptors (Fig. 5E) are scattered over the surface of the animal, especially on the snout, but there are lines of electroreceptor pits on the dorsal and ventral surfaces of the head, and above and below the lateral line of the trunk. Electroreceptors open to the skin surface at a point where several poly- 

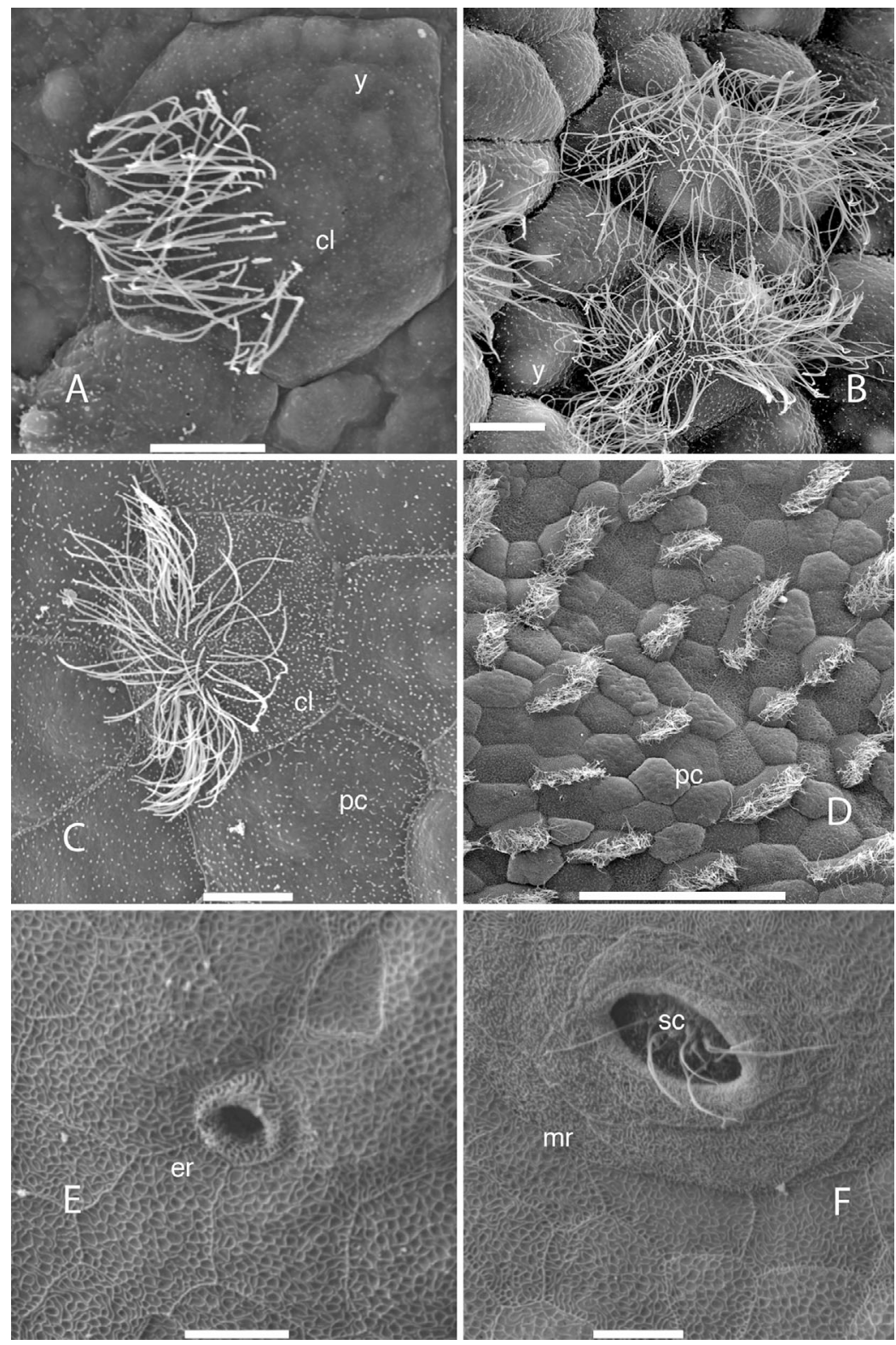

Fig. 5. Neoceratodus forsteri. Skin cells, cilia and sense organs of lungfish embryos and hatchlings from Lowood. (A) Early formation of cilia in the epithelium of a stage 32 embryo. Yolk globules are visible under the cell membrane. Scale bar $=10 \mu \mathrm{m}$. (B) Ciliated cells in the oral cavity of a stage 40 embryo. Cells of the external epithelium do not show yolk globules at this stage, but these are still present in the more heavily yolked endodermal cells of the oral cavity. Scale bar $=10 \mu \mathrm{m}$. (C) Skin of a stage 40 embryo, showing a functional ciliated cell and some differentiation of the polygonal cells surrounding the ciliated cell. Scale bar $=10 \mu \mathrm{m}$. (D) Cells from the trunk of a stage 44 hatchling, showing ciliated cells and differentiation of surrounding polygonal cells. Sizes of cells are similar, and only the ciliated cells are elongated. Scale bar = $100 \mu \mathrm{m}$. (E) An electroreceptor opening to the skin surface in a stage 47 hatchling, surrounded by a corona of skin cells with no particular differentiation. Electroreceptors have no stereocilia. Scale bar $=10 \mu \mathrm{m}$. (F) A mechanoreceptor from the trunk sensory line of the same hatchling, surrounded by differentiated cells and containing stereocilia. Scale bar $=10 \mu \mathrm{m}$. cl: cilia on specialised cell; er: electroreceptor; mr: mechanoreceptor; pc: polygonal cells; sc: stereocilia; y: yolk globules gonal skin cells meet, and consist of a long convoluted tube passing through the epithelium and terminating in a small hollow bulb of cells between the epidermis and the dermis. Mechanoreceptors (Fig. 5F) are associated with the lateral line canals and are regular in occurrence. Mechanoreceptors consist of a bulb of cells surrounding cells with stereocilia, and opening to the surface through a large hole surrounded by specialised epithelial cells (Fig. 5F).

\section{Logan's Inlet specimens}

\section{Progress of development}

Material from Logan's Inlet was highly variable in appearance and in viability. Of the eggs reared in the laboratory that survived for more than $1 \mathrm{~d}, 60 \%$ hatched at around stage 40 . Twenty-five percent of the embryos died before hatching, most of them at stages between 30 and 36, and 9\% hatched too early, at around stage 36 , before they had any developed sense organs and before the muscular system was capable of any coordinated movements. Eyes and olfactory organs had begun to form, but were not capable of receiving any sensory input. Electroreceptors and mechanoreceptors were completely absent, and all the hatchlings could do was respond to repetitive noxious stimuli by flicking the head from side to side (Whiting et al. 1992). At such early stages, the hatchlings were incapable of searching for a suitable hiding place, or choosing a habitat, even if one was available. Most of the eggs from Logan's Inlet that reached a point where hatchlings could be independently viable had left the egg membranes by stage 40 , still without developed sensory organs.

Lungfish embryos and hatchlings, even ones as young as stage 36, move when stimulated (Whiting et al. 1992). Specimens from Logan's Inlet did not 
move much at all. These hatchlings passed through the usual stage of little activity after leaving the egg case, but remained inactive when they should have been moving around. When offered food at the appropriate time, before the yolk was used up, they did not feed. Unlike hatchlings from the Brisbane River, they did not create a clear space around themselves, indicating a lack of ciliary activity. They all died between stages 46 and 48, when the yolk supply was exhausted.

\section{Analysis}

SEM of egg cases from Logan's Inlet showed that the inner membrane of eggs in early stages may have the usual deep folds, but it also contained large holes that expose the outer albumen (Fig. 6). The gaps in the inner membranes allow enzymes from the skin of the hatchling to attack the outer membranes too soon, producing large holes in the egg case and allowing the embryo to fall out of the egg before it was old enough to hatch. The holes in the protective inner membranes also made it possible for fungal hyphae (Saprolegnia sp.) to enter the egg case and infect the embryos, causing death before the embryos were old enough to hatch.

SEM of eggs, embryos and hatchlings from Logan's Inlet showed that these were highly variable in structure and appearance, some approaching the morphologies found in embryos and hatchlings from

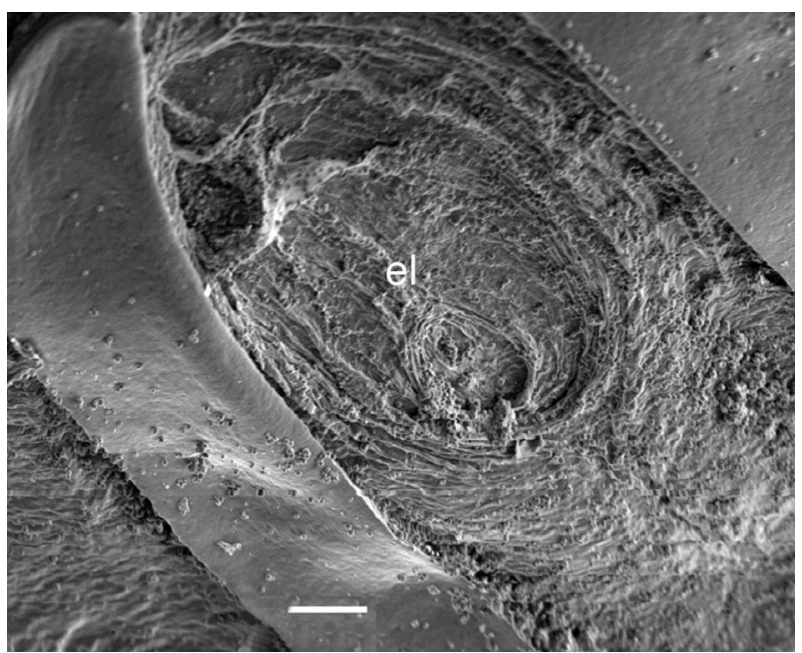

Fig. 6. Neoceratodus forsteri. Scanning electron micrograph of the inner membranes of a lungfish egg from Logan's Inlet. The inner membranes are deficient and the underlying albumen is exposed and has begun to erode. Scale bar = $100 \mu \mathrm{m}$. el: eroded lesion exposing albumen below
Lowood, and others with very different structures. One of the most extreme was an embryo of stage 31 (Fig. 7A). This specimen had a small head extending from the almost triangular endodermal mass, a short tail bud and an almost invisible anus. There was little differentiation of head structure, and no ciliated cells. A second specimen, about stage 43, approaching the usual time of hatching, had many ciliated cells in the epithelium, but the endoderm was grossly distended, and the head was small (Fig. 7B). There was no trace of the pectoral fin behind the operculum, although it should have appeared at this stage. The eyes were present, as was the lateral line of the trunk. Vent, rectum and tail were normal in appearance.

Older specimens were also variable, and despite a superficially ordinary appearance in some of the hatchlings, details varied when compared with hatchlings from Lowood. One specimen, around stage 45 , had a large head, a malformed pectoral fin and mottled skin with no cilia. Myotomes were too obvious under the skin, suggesting that the skin was thin (Fig. 7C). A second hatchling, slightly older, had a tail that looked normal, but the head and pectoral fin were unusual in shape, there were no ciliated cells in the skin, the mouth gaped and the vent was too wide (Fig. 7D). The spine of this fish was twisted, and the dorsal fin did not reach the back of the head, as in hatchlings from Lowood.

Closer examination of the heads of hatchlings from Logan's Inlet confirms that while some specimens from this locality approached the morphologies of material from Lowood (Fig. 8A,C), others showed extremes of structure that were incompatible with life (Fig. 8B,D). Even in a specimen that resembles Lowood material, differences were present (Fig. 8A). The operculum was too small for the stage, as was the pectoral fin. The lateral line of the trunk consisted of isolated mechanoreceptors, not a raised line of cells. There were no cilia, and the skin appeared to have small pustules under the cell membrane (Fig. 8A). The hatchling of stage 48 with head morphology similar to that of Lowood specimens of equivalent age may have had a properly structured mouth, eye and pectoral fin, but the skin of the head was covered in pustules and there were no ciliated cells (Fig. 8C).

One hatchling of stage 46 had a gaping mouth, an operculum twisted outwards revealing misshapen gills below, and skin cells arranged in whorls, with no trace of ciliated cells. The pectoral fin was not present, and the eye protruded (Fig. 8B). Another had a mouth that would not have been able to close, no skin sense organs, no cilia and a smaller than normal 

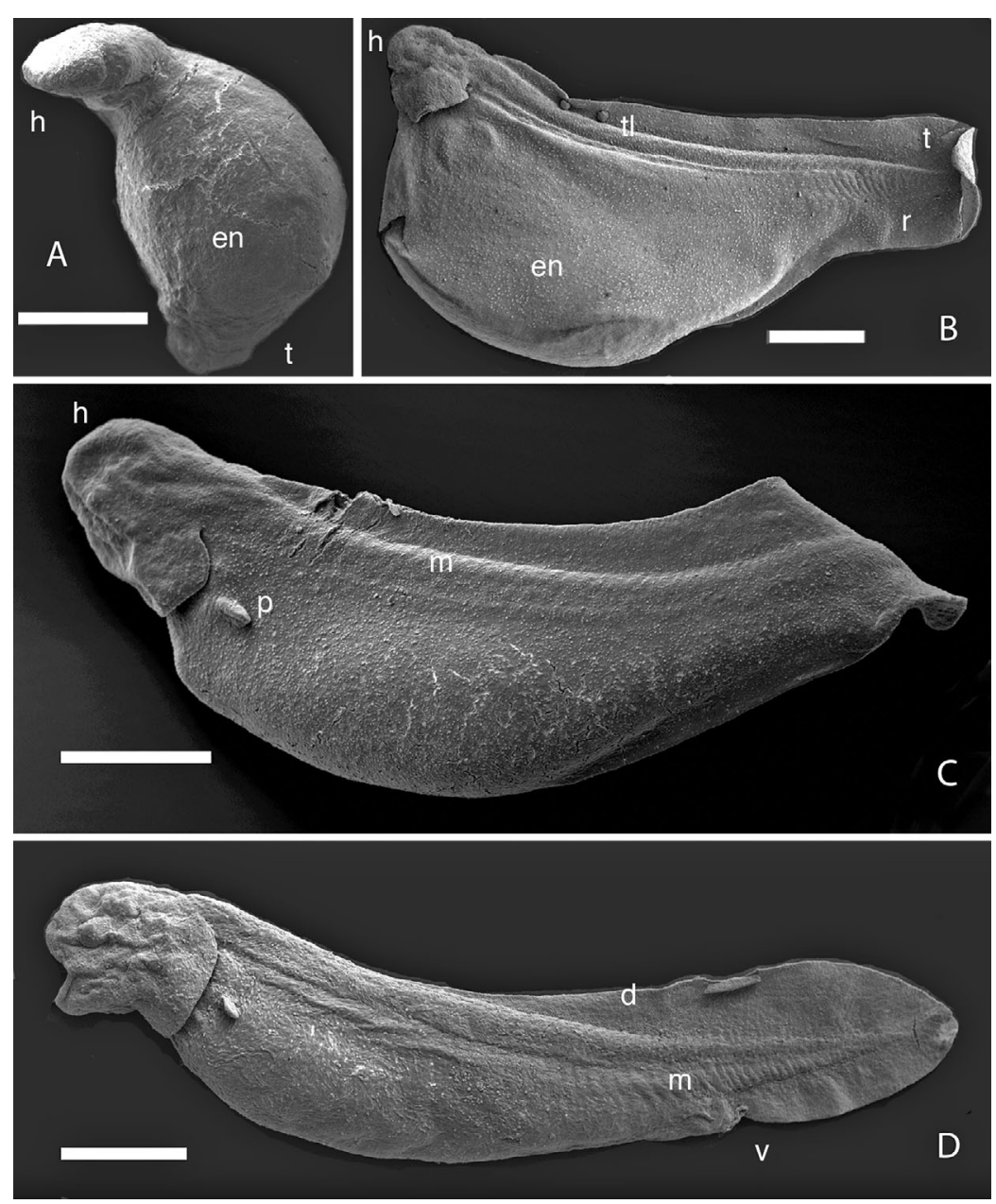

Fig. 7. Neoceratodus forsteri. Lungfish embryos and hatchlings from Logan's Inlet. (A) Ventrolateral view of a stage 31 embryo, with small head extended from the almost triangular endodermal mass, tail bud and anus almost invisible. There is little differentiation of head structure, and no ciliated cells. Scale bar $=1 \mathrm{~mm}$. (B) Lateral view of a stage 43 embryo, with distended endoderm, disproportionately small head and normal tail. There is no primordium of the pectoral fin behind the operculum. The eyes are present, as is the lateral line of the trunk, and the skin is ciliated. Vent and rectum look normal. Scale bar $=$ $1 \mathrm{~mm}$. (C) Dorsolateral view of a stage 45 hatchling, with a disproportionately large head, malformed pectoral fin (detail in Fig. 9C), no cilia visible and myotomes unusually distinct below the epithelium. Scale bar $=1 \mathrm{~mm}$. (D) Lateral view of a stage 47 hatchling, with a gaping mouth, twisted spine, abnormally shaped pectoral fin and vent, no cilia and a dorsal fin that does not reach the back of the head. Scale bar $=1 \mathrm{~mm}$. d: dorsal fin; en: endodermal mass; h: head; m: myotomes; p: pectoral fin; r: rectum; t: tail; tl: trunk lateral line; v: vent

operculum (Fig 8D). Cells of the external epithelium of this fish were arranged in clumps, and the pectoral fin was too small for the stage of development of the rest of the body.

The most fundamental difference between the developing lungfish of Lowood and the material from Logan's Inlet was to be found in the scanning elec- tron micrographs of the skins. The skin of lungfish embryos from Lowood is thick and impervious, and provides an effective barrier to the environment (Bone et al. 1989). Skin cells in embryos and hatchlings from Logan's Inlet, whether the appearance of the whole specimen resembled a Lowood fish or was different in form, had only a thin plasmalemma with a smooth outer surface. Few or no ciliated cells were present in specimens from Logan's Inlet, and the cilia were short and often coated in dirt (Fig. 9B,F). One embryo even had fungal hyphae growing out of the skin cells (Fig. 9A). The egg case belonging to this embryo had large gaps in the inner membranes.

Skin cells of embryos and hatchlings from Logan's Inlet showed considerable variation in size, shape and differentiation in the skin cells, and rarely did this approach the development of the skins of Lowood material (Fig. 5). In some embryos, the skin cells appeared to contain little pustules (Fig. 9B,C), even in animals with morphologies that approached those of Lowood hatchlings (Fig. 9F). Some hatchlings had skin cells arranged in whorls (Fig. 9D) or in rosettes (Fig. 9E). Others had polygonal cells with some structure in the cell membrane (Fig. 9F,G), but the sizes of the cells varied from around $10 \mu \mathrm{m}$ to over $30 \mu \mathrm{m}$. Appearance of the skin cells differed in different areas of the same hatchling. Cells of the skin of the head may be covered in pustules (Fig. 9H) and cells on the trunk may be flat and polygonal (Fig. 9F,G).

Differences were also apparent in the sense organs of the skin. Electroreceptors were generally absent, and the few that were present, although they looked like electroreceptors from Lowood fish (Fig. 9G), were arranged in an irregular manner over the skin surface in places where lines of electroreceptors are found in Lowood hatchlings. Mechanoreceptors, if they were present, had no stereocilia, and no mound of differentiated cells surrounding the opening (Fig. 9H). 

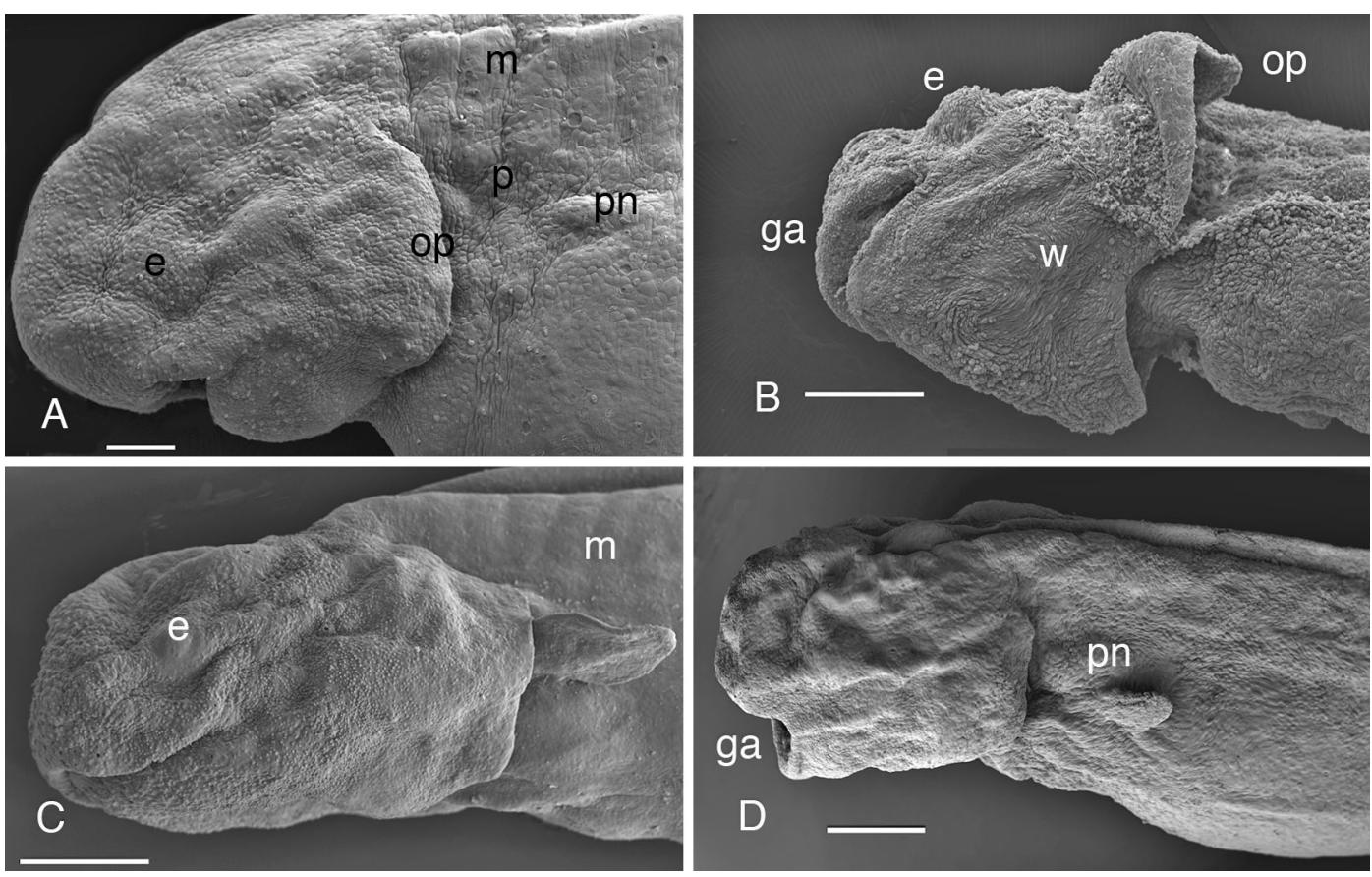

Fig. 8. Neoceratodus forsteri. Heads of lungfish embryos and hatchlings from Logan's Inlet. (A) Head of a stage 42 embryo in lateral view. The operculum is too small for the stage, and the pectoral fin is deformed. The lateral line of the trunk consists of isolated mechanoreceptors, when it should appear at this stage as a line. There are no cilia, and the skin appears to have small pustules under the cell membranes. Scale bar $=200 \mu \mathrm{m}$. (B) Stage 46 hatchling in ventrolateral view, with gaping mouth, operculum twisted outwards, skin cells arranged in whorls (detail in Fig. 9D), no ciliated cells, no pectoral fin and protruding eye. Scale bar $=500 \mu \mathrm{m}$. (C) Head of a stage 48 hatchling, slightly too small to be of normal proportions relative to the trunk, with no cilia and pustular skin. Scale bar $=500 \mu \mathrm{m}$. (D) Lateral view of a stage 47 hatchling, with a deformed head, no cilia and a gaping mouth. Scale bar $=500 \mu \mathrm{m}$. e: eye; ga: gaping mouth; m: myotomes; op: operculum; p: pectoral fin; pn: pronephros; w: whorls of skin cells

\section{DISCUSSION}

Refuges for lungfish hatchlings are essential to maintain the low level of recruitment needed for a species that can live for a long time (Kemp 1995, 2007). Refuges made of submerged water plants or tree rootlets work well in an unaltered natural environment, such as the riverine habitats found at Lowood in the Brisbane River below Lake Wivenhoe. However, few rivers in southeast Queensland are now unaltered; most are affected by the building of dams and reservoirs. These have fluctuating water levels and no permanent water plants in shallow water near the shore during spring when fish are trying to spawn, as in Logan's Inlet in Lake Wivenhoe during the spring of 2009. Unfortunately, the lungfish environment has become so degraded by human activity that many species of fish and other water animals are seriously endangered. The spawning event of 2009 in Lake Wivenhoe, and its outcome, suggests that lungfish in reservoirs face more problems than lack of shelter for the young, and are at risk from additional factors that are yet to be fully identified.
Comparison of Lowood material in the river environment to specimens from Logan's Inlet in the lake environment raises the question of how to define normal development. Young lungfish may have quite unusual structures in the skeleton of the head, such as in the cartilage surrounding the olfactory organs, by comparison with most other small lungfish, but may still be able to find food and avoid enemies (Kemp 2003). Variation is a common attribute of young animals. However, the embryos and hatchlings of Logan's Inlet reared in the laboratory under standard conditions showed extremes of variation, beyond the range of viability. The morphologies of many of these fish were not compatible with the abilities needed to avoid enemies, to keep the skin clean, to find a habitat, to swim, to feed or even to survive.

The spawning event in Lake Wivenhoe in the spring of 2009 was unusual by comparison with spawning in the Brisbane River below the lake. Instead of laying eggs close to water plants with masses of submerged rootlets, eggs were shed free into shallow water close to the shore where there were no refuges for eggs or young fish. The large 

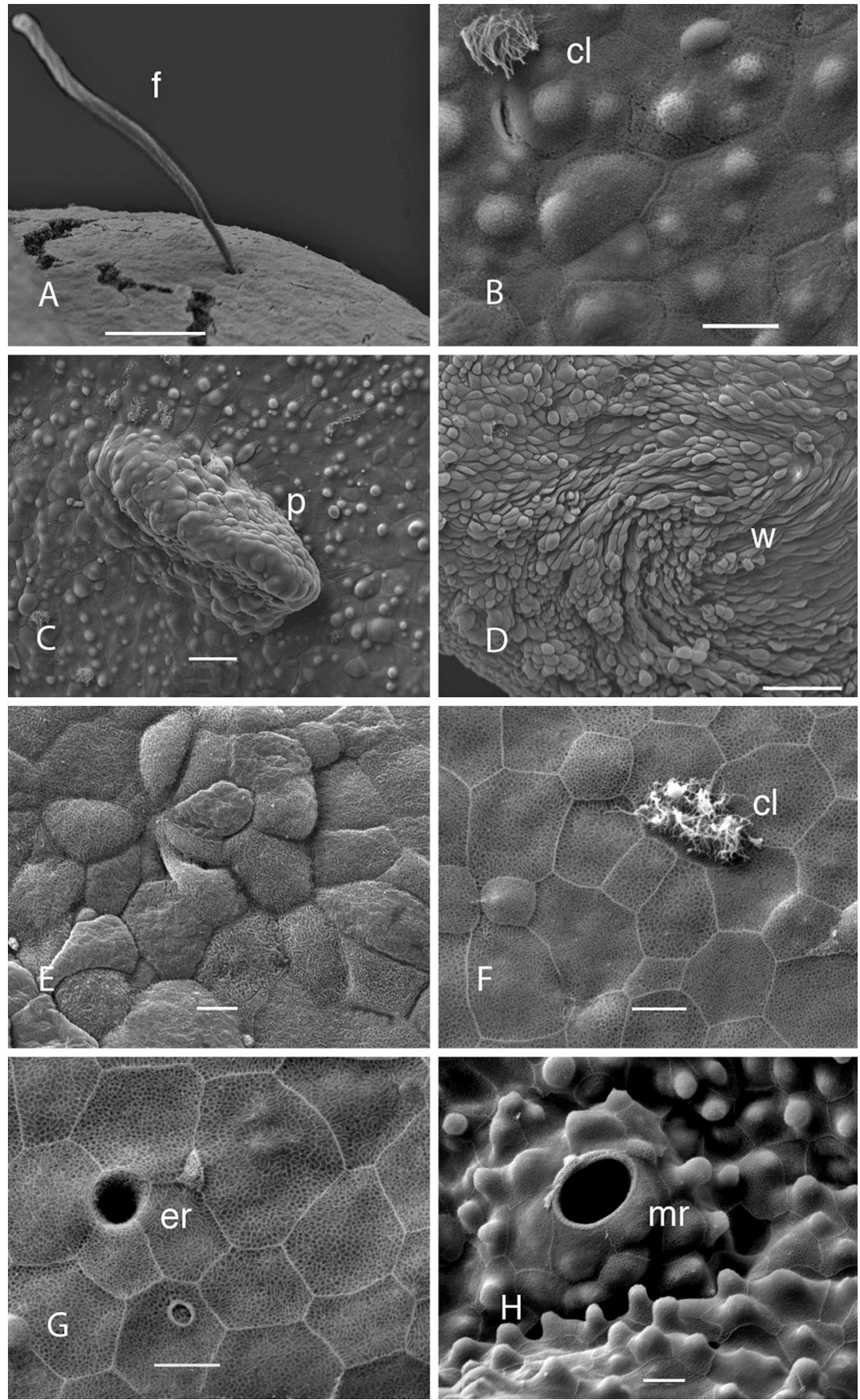

percentage of eggs dead on collection or dying within a day suggests that many of the eggs laid were not fertilised. Many more failed to develop. Of the eggs that survived under laboratory conditions, some died before they could hatch. Others had abnormal egg membranes, which allowed fungal hyphae to enter the eggs and kill the embryos, or caused them to break open too soon and release undeveloped embryos into the water. In the wild, predators would have quickly eaten such early hatching embryos. The embryos that were able to hatch at the correct time had no ciliated cells in the skin, and no way of keeping themselves clean in a foul environment (Kemp 1996). Infection with Aeromonas sp. and Saprolegnia sp., which are common in the environment (Kemp 1994), is a consequence of the absence of cilia or ciliary activity. Infection with chytrid fungus has not been described in lungfish.

Skin sense organs were deficient, even in older hatchlings, so the young fish would not have been able to find suitable refuges or avoid predators. In addition, many hatchlings had deformed mouths and vents. The hatchlings were apparently unable to feed, and all died within 10 wk of hatching, when all of the yolk supply of the egg had been used up (Kemp 1981).

Treatment of the material from Logan's Inlet in the field, and methods of rearing in captivity, do not explain the anomalies found. Lung-

Fig. 9. Neoceratodus forsteri. Skin cells, cilia and sense organs of lungfish embryos and hatchlings from Logan's Inlet. (A) Flank of a stage 32 embryo, with a fungal hypha growing out of the skin. Scale bar $=100 \mu \mathrm{m}$. (B) Skin from a stage 44 hatchling, showing a single ciliated cell and little differentiation of epithelial cells. Scale bar $=20 \mu \mathrm{m}$. (C) Detail of the skin and pectoral fin of the hatchling illustrated in Fig. 7C. The pectoral fin sticks straight out, and the skin has no cilia but appears to contain pustules below the cell membrane. Scale bar $=50 \mu \mathrm{m}$. (D) Skin cells arranged in whorls in the hatchling illustrated in Fig. 8B. Cells are variable in size and show little differentiation. Cilia are absent. Scale bar $=100 \mu \mathrm{m}$. (E) Skin cells in a stage 47 hatchling showing some differentiation but no regular size or arrangement. Scale bar $=10 \mu \mathrm{m}$. (F) Epithelial cells in a stage 48 hatchling, with some differentiation of skin cells and a single ciliated cell. The cilia are short and covered in dirt. Scale bar $=10 \mu \mathrm{m}$. (G) An electroreceptor from the trunk of the same hatchling illustrated in Fig. 9F, with surrounding cells. Scale bar $=10 \mu \mathrm{m}$. $(\mathrm{H})$ Mechanoreceptor from the head of the above hatchling, of the expected size but lacking stereocilia. The sense organ is surrounded by cells apparently containing pustules. Scale bar $=10 \mu \mathrm{m}$. cl: ciliated cell; er: electroreceptor;

f: fungal hypha; mr: mechanoreceptor; p: pectoral fin; w: whorls of skin cells 
fish have a wide range of tolerance to varying temperatures (Kemp 1987), and this has little effect on viability, rate of development, or timing of hatching despite quite large changes in temperature in the water of the rivers during spring. Oxygen levels in the shallow water of the lake should also have been adequate for developing embryos, as it was under laboratory conditions. Material from Logan's Inlet and from Lowood was transported to the laboratory in similar vessels, and reared under identical conditions, in the same culture medium and in the same culture dishes and tanks.

The banks of the Brisbane River and of Lake Wivenhoe are used by farmers, and contamination of the water by agricultural chemicals is possible, but unlikely. Dairy cattle and goats were kept occasionally near the river at Lowood, and beef cattle live on the banks of Lake Wivenhoe. Pesticides used on these animals are either applied in dipping tanks well away from the river, or injected or poured directly onto the animals (W. Jorgensen pers. comm.). These chemicals are not released into the environment. Thus, contamination from agricultural chemicals is not an explanation for anomalous development in the small lungfish from Logan's Inlet, and material from Lowood developed to advanced stages with no problems. Water from the Brisbane River is used to supply the city of Brisbane.

SEM analysis of material collected from Lake Wivenhoe in the summer of 2009 shows why all of the hatchlings raised in captivity died at very early stages of development, and why it is probable that very few, if any, have survived in the wild from the spawning event of 2009. In addition to problems with a lack of refuges and food available for young fish, inherent in the environment of Lake Wivenhoe, which has fluctuating water levels, the young raised in captivity had many abnormalities in the skin alone. Given the anomalies of the jaws and skin, it is hardly surprising that none of the hatchlings began to feed, and that all were dead by stage 48 .

Understanding of the effects of nutrition in animals has important implications for conservation studies (Wikelski \& Cooke 2006). If the adult lungfish have not had appropriate food in the months prior to spawning, it is possible that, rather than producing fewer eggs, they produce eggs that do not contain enough of the nutrients required by young fish for correct development. The eggs may be deficient in volatile fatty acids, known to affect viability and development of teleost eggs (Peleteiro et al. 1995, Furuita et al. 2003) and may also lack more ordinary nutrients such as proteins and carbohydrates. As a result, eggs may not be viable or able to complete development of important structures such as cilia in the skin and sense organs. The adult fish dying in a flood-related event in Lake Wivenhoe in July 2009 had empty intestines and were living on their reserves, because Lake Wivenhoe had little suitable food for the adults (author's unpubl. report). The same situation has occurred in the Brisbane River below the reservoir and may be responsible for the cessation of spawning in Lowood in 2002. A male fish, caught illegally and left to die on the bank of the river at Lowood in 2002, had undeveloped testes and no food in the intestine (author's unpubl. report).

Many factors control the health and viability of eggs and young hatchlings. These could be genetic, or could be related to the age of the parents. Maternal malnutrition could be involved, reducing the viability of the eggs. Water quality must play a part as well. The way that the adult fish lay the eggs, free in the water column or among water plants, may affect the outcome of a spawning event. The presence of suitable and permanent refuges for eggs and hatchlings is also important. It is possible that eggs from different places vary in their ability to grow, hatch and form young adults. The spawning event of 2009, abnormal though it was, has raised many new questions.

The spawning event involving lungfish in Wivenhoe Reservoir in 2009 has been described as a 'good news' story (Queensland Government 2010), and has been used as evidence that lungfish are not endangered in their habitats. In addition, it is claimed that lungfish habitats are managed well by the Queensland Government and its agencies (Queensland Government 2010). The evidence from the present study suggests otherwise.

Acknowledgements. This work was carried out with the permission of the Queensland Government Department of Primary Industries and Fisheries, permit number 92060 and the Animal Ethics committee of Queensland University, permit number CMS/350/09. Dr. W. Jorgensen of the Queensland Department of Primary Industries and Fisheries (DPIF) provided information on pesticides; and staff of the Brisbane Forest Park and the DPIF provided information on the current status of lungfish in the Enoggera Reservoir. The research was funded by grants from the Adelphi Australia Science Foundation and from the Australia and Pacific Science Foundation. Thanks also to staff of the Centre for Microscopy and Microanalysis at the University of Queensland for advice and help with SEM, and to friends and family who assisted with the collection of eggs from Lowood and Logan's Inlet. 


\section{LITERATURE CITED}

Bancroft TL (1912) On a weak point in the life-history of Neoceratodus forsteri Krefft. Proc R Soc Queensl 23: 251-256

Bancroft TL (1913) On an easy and certain method of hatching Ceratodus ova. Proc R Soc Queensl 25:1-3

Bancroft TL (1918) Some further notes on the life-history of Ceratodus forsteri. Proc R Soc Queensl 30:91-94

Bennett WR, Edmondson G, Lane ED, Morgan J (2005) Juvenile white sturgeon (Acipenser transmontanus) habitat and distribution in the Lower Fraser River, downstream of Hope, BC, Canada. J Appl Ichthyol 21:375-380

Bone Q, Kemp A, Kemp D (1989) Epithelial action potentials in embryos of the Australian lungfish. Proc R Soc Lond B Biol Sci 237:127-131

Duke P, Anders Ennis G, Hallock R, Hammond J and others (1999) Recovery plan for Kootenai River white sturgeon (Acipenser transmontanus). J Appl Ichthyol 15:157-163

Frentiu FD, Ovenden JR, Street R (2001) Australian lungfish (Neoceratodus forsteri: Dipnoi) have low genetic variation at allozyme and mitochondrial DNA loci: a conservation alert? Conserv Genet 2:63-67

Furuita H, Ohta H, Unuma T, Tanaka H, Kagawa H, Suzuki N, Yamamoto N (2003) Biochemical composition of eggs in relation to egg quality in the Japanese eel, Anguilla japonica. Fish Physiol Biochem 29:37-46

Grigg GC (1965) Spawning behaviour in the Queensland lungfish, Neoceratodus forsteri. Aust Nat Hist 15:75

> Hagenmaier HE (1973) The hatching process in fish embryos. III. The structure, polysaccharide and protein cytochemistry of the chorion of the trout egg, Salmo gairdneri (Rich.). Acta Histochem 47:61-69

Hagenmaier HE (1974) The hatching process in fish embryos. V. Characterization of the hatching proteases (chorionase) from the perivitelline fluid of the rainbow trout, Salmo gairdneri Rich. as a metalloenzyme. Wilhelm Roux Arch 175:163-172

Iuchi I, Yamagami K (1976) Major glycoproteins solubilized from the teleostean egg membrane by the action of the hatching enzyme. Biochim Biophys Acta 453:240-249

Kemp A (1981) Rearing of embryos and larvae of the Australian lungfish, Neoceratodus forsteri (Krefft) under laboratory conditions. Copeia 1981:776-784

Kemp A (1982) The embryological development of the Queensland lungfish, Neoceratodus forsteri (Krefft). Mem Queensl Mus 20:553-597

Kemp A (1984) Spawning of the Australian lungfish, Neoceratodus forsteri (Krefft) in the Brisbane River and in Enoggera Reservoir, Queensland. Mem Queensl Mus 21:391-399

Kemp A (1987) The biology of the Australian lungfish, Neoceratodus forsteri. J Morphol 190 (Suppl 1):181-198

Kemp A (1994) Pathology in eggs, embryos, and hatchlings of Neoceratodus forsteri (Osteichthyes: Dipnoi). Copeia 1994:935-943

Editorial responsibility: Steven Cooke, Ottawa, Ontario, Canada
Kemp A (1995) Threatened fishes of the world: Neoceratodus forsteri (Krefft, 1870) (Neoceratodontidae). Environ Biol Fishes 43:310

Kemp A (1996) The role of epidermal cilia in development of the Australian lungfish, Neoceratodus forsteri (Osteichthyes: Dipnoi). J Morphol 228:203-221

Kemp A (1997a) A revision of Australian Mesozoic and Cenozoic lungfish of the Family Neoceratodontidae (Osteichthyes: Dipnoi) with a description of four new species. J Paleontol 71:713-733

Kemp A (1997b) Four new fossil dipnoans of the genus Metaceratodus (Osteichthyes: Dipnoi, Family Ceratodontidae). J Vertebr Paleontol 17:26-33

- Kemp A (1999) Ontogeny of the skull of the Australian lungfish, Neoceratodus forsteri (Osteichthyes: Dipnoi). J Zool 248:97-137

Kemp A (2003) Anomalies in the developing chondral and visceral skeleton of the Australian lungfish, Neoceratodus forsteri (Osteichthyes: Dipnoi). Ann Anat 185: 121-134

Kemp A (2005) New insights into ancient environments using dental characters in Australian cainozoic lungfish. Alcheringa 29:123-149

Kemp A (2007) The natural history of the Australian lungfish. Available at www.annekempslungfish.com/naturalhistory.pdf

Kind PK (2011) The natural history of the Australian lungfish Neoceratodus forsteri (Krefft, 1870). In: Jorgensen JM, Joss J (eds) Biology of lungfishes. CRC Press, Enfield, $\mathrm{NH}, \mathrm{p} 61-96$

Lissone I (2003) Conservation genetics and the Australian lungfish Neoceratodus forsteri (Krefft, 1870); a spatiotemporal study of population structure. MSc thesis, The University of the Sunshine Coast, Sippy Downs

Peleteiro JB, Lavens P, Rodriguez-Ojea G, Inglesias J (1995) Relationship between egg quality and fatty acid content of various turbot broodstocks (Scophthalmus maximus L.). ICES Mar Sci Symp 201:51-56

Queensland Government (2010) Lungfish breeding in Wivenhoe Dam is good news. Ministerial Media Statement, Aug 11, Queensland Government, Brisbane. www. cabinet.qld.gov.au/mms/StatementDisplaySingle.aspx? id $=71050$

Semon R (1893a) In the Australian bush and on the coast of the Coral Sea, being the experiences and observations of a naturalist in Australia, New Guinea and the Moluccas. Macmillan and Co, London

Semon R (1893b) Die äussere Entwickelung des Ceratodus forsteri. Denkschr Med-Naturwiss Ges Jena 4:29-50

> Whiting HP, Bannister LH, Barwick RE, Bone Q (1992) Early locomotor behaviour and the structure of the nervous system in embryos and larvae of the Australian lungfish, Neoceratodus forsteri. J Zool 226:175-198

Wikelski M, Cooke SJ (2006) Conservation physiology. Trends Ecol Evol 21:38-46

Submitted: March 7, 2011; Accepted: May 22, 2011

Proofs received from author(s): October 19, 2011 